\title{
Practice Firms and Networked Learning: Matches and Mismatches
}

\author{
Jorge Alberto dos Santos ${ }^{1}$
}

\begin{abstract}
This paper is concerned with how students describe their experiences of the Practice Firms Network learning environment (PFN) within a management course in a private institution of higher education in Brazil (Faculty Pitágoras-Mg). The work is derived from a broader study where I investigated the PFN concept as it is used in the Brazilian context. The students' description of their relationship with the PFN model is made the object of study in a phenomenographic perspective (Marton, 1986; Marton and Booth, 1997). The paper discusses the data and results of the research and concludes that the model is potentially effective to link participants in management education but that it has yet to learn how to use more effectively the power of information technology. From students' descriptions, flaws in the model derive from the following features: a) The model itself does not stress networked learning; b) The infrastructure does not support the design; and c) The teachers' approach to the model is not congruent.
\end{abstract}

Keywords: Management Education, Practice Firms, Phenomenography

\section{Resumo}

Este artigo relata como estudantes de graduação de uma instituição de ensino superior no Brasil (Faculdade Pitágoras$\mathrm{Mg}$ ) descrevem suas experiências com o modelo de Empresas Simuladas. Este artigo é parte de um estudo mais amplo onde eu investigo como o modelo de Empresas Simuladas é utilizado no contexto brasileiro. A descrição do modelo é tomada como meu objeto de estudo numa perspectiva fenomenográfica (Marton, 1986; Marton and Booth, 1997). O artigo discute os dados e resultados da pesquisa e conclui que o modelo é potencialmente efetivo para interligar estudantes de cursos de Administração mas que o modelo ainda necessita reconhecer melhor o poder da tecnologia da informação. Das descrições dos estudantes, fraquezas do modelo derivam das seguintes características: a) o modelo em si não enfatiza o ensino à distância; b) a infra-estrutura não apóia o modelo; c) a abordagem dos professores ao modelo não é consistente.

Palavras-chave: Educação em Administração, Empresas Simuladas, Fenomenografia

\section{The Practice Firms Network Learning Environment}

The PFN model as used in the Brazilian educational system is a learning environment in management education where groups of approximately fifteen students run simulated enterprises performing the role of staff - clerical officers and managers - of the enterprise. Each simulated enterprise - called here a Practice Firm Unit (Pfu) or simply a Practice Firm (Pf) conceptualizes and sells a range of virtual products to people around the model. The set of all Pfus and people around this model of management education constitute a network which is called in this work the Practice Firms Network Learning Environment (PFN). Although the PFN concept is introduced in the curricular programme of Faculty Pitagoras as a discipline, it should be noted that the PFN model constitutes a network of students and staff potentially connected - physically through trade fairs events

${ }^{1}$ Mestre em Administração pela UFMG Doutorando em Ensino de Administração pela Lancaster University-UK.Endereço: Rod. MG 120, Km 45 - Bairro Joao Brás - Viçosa/Minas Gerais- Brasil - CEP: 36570000 - Email:jalberto@ufv.br

Artigo submetido em julho de 2007 e aceito em maio de 2008 
and virtually through ICT (Information and Communication Technology) - in 29 countries around the world (see www.europen.de ). The model may be viewed as composed of five elements:

- The Europen Organization: the organization which coordinates and operates the model globally;

- The Central Offices: a local organization which is accountable for coordinating the operation of the PFN model within a country;

- The Practice Firms Units (Pfus): enterprises that are organized within the educational institutions, with groups ranging from five to fifteen students who perform the roles of employees and managers of the firm;

- The Market of Practice Firms: the market is constituted, on the supply side, by the set of products and services that are offered by the Pfus, and on the demand side, by the students, teachers, other Pfus and people who surround the model;

- The Business Partners: a real company from the real economy and usually from the same sector in which the Pfu has decided to run its business that provides a link between the Pfu and the real market, to give support, business information and assistance to the students in respect of the functioning of the real market.

According to Tramm (cited in Gramlinger, 2004), the PFN concept may have several goals depending on the learning purposes of the institution: a) a place for concentration and practice; b) a place of training for practice; and c) a genuine learning place. The basic difference among these perspectives is a transition from a view of knowledge as a commodity to be transmitted to a view of knowledge as meaning to be elaborated (Boot and Hodgson, 1987).

\section{The Purpose of the Study}

The purpose of the main work was to investigate and categorize students' perceptions and descriptions of the PFN model in Brazil. In this paper, I specifically concentrate my analysis on the Faculty Pitágoras students - as they are the undergraduate students in the sample - and on how the PFN model relates to network learning.

'Networked management learning' is defined in the literature as "learning by managers that is supported by ICT (information and communications technology) used to connect learners with, in particular, other people (learners, teachers/tutors, mentors, librarians, technical assistants, etc.) as well as to learning resources and information of various kinds and types" (Hodgson and Watland, 2004: 99). Human-human interaction is still considered an important part of this social practice (Goodyear et al., 2004). Since one could argue that PFN students are not 'managers' yet, we should broaden the definition to include management students or 'managers-to-be' as this is one of the aims of the PFN model. Moreover, it should be noted that the discussion here is not technology-driven, that is, it is not directed to aspects of how networked learning could be supported in the model but conversely, model-based or how the technology is actually being used and how it could be used to improve the model.

\section{Justification of the Work}

Lectures continue to be a dominant pedagogical instrument in the educational system (schools, colleges, universities) and have been thoroughly studied (to refer to studies on lectures see Hodgson $(1980,1997)$ and Bligh (1971, 2000). Nonetheless, Mintzberg (2004) notes that "business schools have not been inclined to stop [in classroom-based experience] ... and have looked far and wide for other pedagogical methods, especially in search of that "real world" of managing" (p. 43). Some of these methodologies include action learning (Revans, 1998), venture planning courses (Pittaway, 2004) and service-learning (Wankel and DeFillippi, 2002). The search for new methods to teach and learn about management is justified by many reasons. Among those reasons the following should be mentioned: 
a) Managers and trainers complain that school leavers are not very good at thinking for themselves (Jones, 1989);

b) Management education has never been seriously considered (Mintzberg, 2004);

c) A survey conducted by Andrade et al. (1999) with managers, teachers and employers in Brazil showed that these groups had several concerns about the education that had been offered by management schools. The research concluded that among the management professionals in Brazil only $7.8 \%$ considered that the course they had concluded offered them a "very good" preparation for the work of management. One of the reasons pointed out by the professionals was that their "university degree [was] excessively generic [and] diverted from a commitment with a work-based area" (p. 80).

In conclusion, the literature suggests the existence of gaps between the world of work and the academic world. It seems that "we do not yet know well how to design effective instruction for complex domains" (Spector, 2000). The PFN initiative is a tentative move in order to fill these gaps. Nevertheless, few works have addressed the question of the nature of the PFN concept in the literature and none of them have specifically studied the nature of the relationship between students and this learning environment from a student perspective.

\section{Methodology}

The research uses a phenomenographic approach. Phenomenography is defined as an empirically based approach to research that aims at "mapping the qualitatively different ways in which people experience, conceptualise, perceive, and understand various aspects of, and phenomena in, the world around them" (Marton, 1986: 31). Phenomenography aims to explore some aspects of a "hidden world of human conception" (p.33).

Phenomenography links researcher, the phenomena researched and the subjects researched in a second-order perspective. This means that what interests phenomenographic research is to describe "what the researched subjects think something is" differentially from a first-order perspective that is interested only in describing "what the phenomenon researched is". In the first-order perspective, "the ways of experiencing the world, the phenomena, the situations, are usually taken-for-granted, tacit, transparent" (Marton, 1996: 185). In the secondorder perspective, these ways of experiencing the world, the phenomena and the situations are not taken-forgranted; instead they are made the object of study.

\section{The Sample and the Method of Data Collection}

Twenty-nine students from two educational institutions in Brazil - the SEBRAE Managerial Technical School (ETFG) and Faculty Pitágoras - took part in the main research. In this paper, I specifically focus on Pitágoras students' description of their experience, as they were the undergraduate students of the sample. Nine students were interviewed in Faculty Pitágoras. Faculty Pitágoras had implemented the PFN model in the programme recently and students interviewed in the research were the first class to have used the model in the Faculty. Students' interviews were semi-structured. Students were presented with an 'introductory paper' asking them to describe three happenings in their experience of the Practice Firms. Their recounted narrative was then followed with 'furthering questions' which arose as they progressed in the descriptions of their experiences.

\section{The Outcomes of the Work}

The analysis of the data showed that the description of the PFN given by Pitagoras students could be categorized in seven different ways. The PFN model was seen by the students as a:

a) Pointless experience;

b) School experience; 
c) Group Work experience;

d) Competitive experience;

e) Simulated experience;

f) Way of Learning experience;

g) Realistic experience.

I describe below the meaning of each category that I was able to construct from student descriptions of their experience with the PFN model. The description of the categories will be followed by some short quotations:

\section{The PFN as a Pointless Experience}

A 'pointless' experience describes students' description of the PFN model as a learning environment which they regarded as meaningless. In this way, in referring to a 'pointless' experience what interviewees seemed to express was that taking part in the PFN had not benefited their learning experience. Students expressing this way of referring to the PFN felt that the experience had been 'loose' and 'confused'. Moreover, students expressed the idea that they had completed the "discipline" because they were obliged to do so by the curriculum. Therefore, it was an external demand on them, not their personal choice. As stated by one student,

by and large we took the Practice Firm discipline ... it was a compulsory discipline and we had to do it because of the grade... otherwise we wouldn't do it ... anyway ... it was terrible ... a lot of problems ... anything you can imagine ... our class didn't like it ... actually ... on the last day [of the term] we celebrated the end of the Practice Firm... (Pita-06)

\section{The PFN as a School Experience}

In this category, the PFN was seen as similar to any other academic school discipline, such as Maths and Science. Students focused on the fact that the PFN was part of the curriculum, was compulsory and that the Faculty and the teachers defined the rules that students should follow in the 'discipline'. As a consequence of that, student priorities were centred on satisfying the demands of tutors and the way in which assessments were to be marked. For example, because the following student had changed class during the term $\mathrm{s} / \mathrm{he}$ described how $\mathrm{s}$ /he differentiated the 'morning' class from the 'evening' class. In both, s/he emphasizes the characteristics of the PFN as a 'class' and as a 'discipline'

... the evening class was enormous ... each work group had fourteen to fifteen students ... my morning class had only sixteen students ... so we divided the class into two groups of eight students ... each Practice Firm had eight people ... I think that was much better than the evening class ... in the evening class it was difficult to find tasks to share among the students ... on the contrary ... in the morning class each one had much more work to do than one could cope with ... and the project was the same ... the discipline was the same ... (Pita-06)

\section{The PFN as a Group Work Experience}

A 'group work' category was defined when students perceived that they were performing in the PFN as a group or in a group and not individually; when they noticed the importance of the group or the necessity of others in order to accomplish his/her part of the job in the model. In this category, students perceived 'group work' and 'working in teams' as the relevant unit of the pedagogical practice in the learning environment. Group work in the PFN sometimes corresponded to sectors, departments or functions as in real enterprises. To give one example: 
... the philosophy of the faculty in all disciplines is teamwork ... and this was really stressed in the Practice Firm ... that's when we noticed the importance of teamwork ... (Pita-03)

\section{The PFN as a Competitive Experience}

The PFN as a competitive experience emphasized the rivalry between the Pfus or even between individuals in the PFN model. Describing the PFN explicitly in this way was rare in the interviews. One explicit statement of this category is given in the citation below

[The trade fairs] ... were very impressive ... we made sales ... symbolic sales ... the customers did not take the product ... but they went out with the sales impressed on their mind ... there was a great competition between the Practice Firms in the Faculty ... it was a competition ... (Pita-05)

\section{The PFN as a Simulated Learning Environment}

The PFN experienced as a simulated learning environment was seen as a model or as a laboratory where business processes were being simulated. In this view, students perceived the PFN as trying to imitate the real world. Although the students were conscious that what they were doing was not 'real', they engaged in the learning situation to play a role and, in doing that, they usually believed that the experience was important to understand how things would be in the 'real world'. For example,

I think that the project is the opportunity to see how a real enterprise works ... to experience everything that happens in a [real] enterprise ... the difficult times ... the crisis moments ... financial crisis ... personal crisis ... administration ... the starting up ... (Pita-07)

\section{The PFN as a Way of Learning Experience}

I called this category a 'Way of Learning' experience to emphasize the fact that students begin to stress how and what they had learnt through the PFN experience. This category is qualitatively different from the previous ones, not only because students are getting something out of the experience, but also because students began to perceive how this was happening. For instance, sometimes they learnt because they were performing tasks, sometimes because they had committed mistakes and sometimes by observing peers or teacher's attitudes. The following quotation expresses such a view

My experience ... that was the most significant ... was that I had the idea of exactly how the finance function of the enterprise works ... as I was in charge of the finance sector ... from the start up period ... all types of spending ... payment slips... everything ... I had to pay attention to this all ... although we had studied four years I had no practical experience in this area ...the finance area ... this gave me a lot of experience ... I know that I can go into the finance sector now and won't feel lost ... (Pita-04)

\section{The PFN as a Realistic Experience}

Realistic was considered here in opposition to 'simulated'. In this category, the PFN was seen as incorporating real enterprise processes. However, the perception of the PFN as a real enterprise process does not mean that the participants were alienated by the pedagogical and virtual nature of the concept. The processes that happened in the learning environment were experienced as 'real' in their own right, that is, the simulated character of the learning environment was disregarded and the processes that constituted the learning experience were experienced in a lively way. One example is

We searched for a partner ... the Coluninha [name of the Partner Company] really existed ... one of our group mates was a relative of one of the directors of the company ... and at our first trade fair he brought all types of products he had in the company ... in order to promote their company ... the outstanding point in all the project was that ... our enterprise ... he proposed that we went real ... he liked our work so much ... and this would be interesting for him ... for his enterprise was a small company ... it lacked promotion ... and our company would do that for him ... (Pita-02) 
This set of categories - as shown above - composed what, in a phenomenographic approach, is called the 'outcome space'.

\section{Conclusion and Discussion}

With respect to an overall perception of the model, the research data showed that Pitágoras students' outcome space of the PFN model could be arranged in two dimensions: one dimension which I called the meaning dimension and another which I termed the structural dimension. These two dimensions in which students experienced the PFN model are in line with Marton and Booth's (1997) observation that meaning and structure, "are dialectically intertwined and occur simultaneously when we experience something" (p. 87). We may say, therefore, that experiencing something has a meaning (referential) and a structural aspect. Diagrammatically, in relation to the data of the research, these two dimensions can be shown as in the table below. What the table shows is an arrangement of the seven categories as described above within the two dimensions.

Table 1 - The Structure of the Outcome Space of Pitágoras Students' Experience of the PFN

\begin{tabular}{ll}
\hline $\begin{array}{l}\text { Meaning Dimension } \\
\text { Categories }\end{array}$ & $\begin{array}{l}\text { Structural Dimension } \\
\text { Categories }\end{array}$ \\
\hline
\end{tabular}

a) Pointless Experience

a) School Experience

b) Group Work Experience

b) Way of Learning Experience

c) Competitive Experience

c) Realistic Experience

d) Simulation Experience

Source: Research Data

The meaning dimension of Pitágoras students' descriptions showed that the range of variation could be arranged to demonstrate that students experienced the model from a completely 'pointless experience' to a 'realistic involvement' with the PFN. The meaning dimension demonstrated that students devalued the PFN model when they perceived it as a 'pointless' experience and students valued the PFN model when they perceived it as aggregating meaning to their experience.

On the other hand, the structural dimension of Pitágoras students' descriptions showed that students perceived the PFN model in structured ways (whether these be academic disciplines, group work, competition or simulations) that helped them to deal with tasks and situations in the model. However, what sort and relevance of learning they took out of these events and situations was considered contextual, that is, dependent on things such as the teacher's orientation to the model, the demand of the task or the congruence between the task and the reality which the task intended to reproduce.

With respect to networked learning, Pitágoras students' categorization of the model does not immediately show the potential of the PFN environment for the promotion of connections between learners, learners and tutors and between a learning community and its learning resources (Goodyear et al., 2004) through the use of ICT (Information and Communication Technology). The reason for that - extracted from students' descriptions can be summarized in three streams of thought: 
a) The model itself does not stress the feature;

b) The infrastructure does not support the design;

c) The teachers' approach to the model is not congruent;

a) The model itself does not stress the feature: although the design of the model - as pointed out by their sponsors - emphasizes the potential link among a broad range of participants, actually the model stresses face to face interactions through the trade fairs events. The 'Trade Fair' event turned out to be the most frequent incident described in the data by the students and in some aspects, the most important. As described by this student, the trade fair is

an event ... organized by the educational institution ... that opens the institution doors to the public ... and turns us into [entrepreneurs] ... we have to sell our products ... in a simulated way ... to the public ... and other Practice Firms entrepreneurs ... from PUC, SEBRAE ${ }^{1}$... the intention of the trade fair is to give the Practice Firms the opportunity to show their products and sales ... the trade fair is a very outstanding point in the Practice Firm project ... [...] ... [and] ... the most significant moment in the experience of the Practice Firm Network ...(Pita-01)

As shown by some students descriptions and implicit in the categories that I have called 'pointless' and 'school' experience, the motive for networking in the model sometimes was viewed as a teacher-imposed demand for performance. For example,

...on the trade fair day ... as the enterprise [the group] was being assessed ... everyone committed to the work [the Practice Firm] ... (Pita-02)

Moreover, the basic idea of network in the model is social networking - network that is about connection of individuals and groups and has nothing to do with technology, although the presence of information technology may enhance the promotion of connections (Goodyear et al., 2005).

b) The infrastructure does not support the design: another feature that inhibits networked learning in the model is the fact that even connections between students and basic resources were perceived as fragile in the model. Students claimed that, sometimes, information was not available or they were not easily accessible in the system. As put by this student,

we needed some reports ... something ... basically from the bank ${ }^{2}$... and we had no access ... this harmed our work a little... (Pita-09)

or again, that the supposed Practice Firm market (demand and supply links) was not functioning, causing frustration and disillusion with the model

we made contacts with other Practice Firms ... but we couldn't make sales [through these contacts] ... in fact almost anybody in the Faculty could make any sale ... [through the simulated market] ... [...] ... we sent emails to other Practice Firms [to advertise our products] ... SEBRAE ... PUC ... and we didn't have a reply ... this is something that was very frustrating ... (Pita-07)

Most of the time, the literature takes infrastructure for granted but in countries where technological infrastructure is an issue, this feature must be taken into account.

c) The teachers' approach to the model was not congruent: the most significant and probably debatable feature that should be addressed to achieve a better exploitation of the networked nature of the model is the teachers' approach to the model. Although the aim in my main research was not to elaborate directly on the approach of teachers to the model, it was clear from students' descriptions that the role teachers played in the model greatly affected their own approach.

The approach of the teacher to learning - or conceptions of teaching - has been documented in the literature (Prosser and Trigwell, 1999; Roberts, 2004). One basic distinction is that there are content-oriented teachers 
and student-focused teachers. The intention of the former is to "transfer information or concepts to students by teacher-focused strategies" (Robert, 2004: 223) while the purpose of the latter is to help "students develop or change their understanding of key ideas" (p. 223). Robert suggests that teachers' disposition to use networked learning is affected by many sources of pressures In summary, the author concludes that "networked learning is more likely to be adopted by teachers whose motivation is learning enhancement ... [and] ... that where the declining unit of resource is impacting on teaching loads, there is less likelihood of networked learning being adopted" (p. 243).

In the PFN model, partially due to the novelty of the model in Faculty Pitágoras, students perceived other sorts of pressure. For example, some students perceived that the model had burdened teachers with "a new social setting and a new role" (Gramlinger, 2004:.88) in which

the teachers were not prepared to deliver the Practice Firm discipline ... not because they were bad teachers ... they were not ... but they weren't prepared to face the Practice Firm discipline ... it is completely different ... the way to present the discipline ... it is completely different from a lecture ... [from] ... the didactic approach you have to use in a lecture ... (Pita-06)

To accept these new challenges, teachers would have to be persuaded and prepared. However, change in the disposition of teachers to adopt a different approach to their teaching may take time to effect.

\section{Final Remarks}

In the PFN model, the idea of networking learning begins with the basic idea of social networking, that is, a group of people around a pedagogical device for the aim of promoting management education by imitating real enterprises. The designers of the model should investigate further the possibility that there would be certain groups (besides target-students and teachers) who could be interested in a more participative way of being linked to the network. Which people and what interests would attract those people around the model would have to be researched.

Although the trade fairs are a very important feature of the model, they should give space to more networked relationships among the participants. As they stand, the links made possible by the model are predominantly customer-supplier-type relationships. Nonetheless, the model could also afford prominence to networking in other ways. Although some effort has been put into this - see, for example, the websites of any central office in the model - IT potential has expanded rapidly and the model should follow this tendency.

Finally, it should be stressed that the model put a different sort of burden on the role of teachers. Without preparation of teachers for and their acceptance of these new roles, the model may be undermined by a lack of commitment and implicit or explicit acts of rejection. Teachers' conception of networked learning is important and the situation here has a bi-directional aspect: teachers' concept of networked learning may improve or undermine the model and the chances of the latter alternative increases if the model does not learn how to use effectively the power of IT technology. 


\section{References}

Andrade, R., M. Correia, et al. (1999). Perfil, Formação e Oportunidade de Trabalho do Administrador Profissional. São Paulo, ESPM.

Bligh, D. (1971, 2000). What's the Use of Lectures? San Francisco, Jossey-Bass.

Boot, R. and V. Hodgson (1987). Open Learning: Meaning and Experience. Beyond Distance Teaching - Towards Open Learning. V. E. Hodgson, S. J. Mann and R. Snell, Open University Press.

Goodyear, P., S. Banks, et al. (2004). Research on Networked Learning: an Overview. Advances in Research on Networked Learning. P. Goodyear, S. Banks, V. Hodgson and D. McConnell. Boston, Kluwer Academic Publishers.

Gramlinger, F. (2004). The Advantagens and Disadvantagens of Learning and Teaching in a Practice Firm. New Approaches to Vocational Education in Europe: the Construction of Complex Learning-Teaching Arrangements. R. H. Mulder and P. F. E. Sloane. Oxford, Symposium Books.

Hodgson, V. (1980). Lecturing and Learning: a Study of Student's Experience. Surrey, University of Surrey. PhD.

Hodgson, V. (1997). Lectures and the Experience of Relevance. The Experience of Learning. F. Marton, D. Hounsell and N. Entwistle. Edinburgh, Scottish Academic Press.

Hodgson, V. and P. Watland (2004). "Researching Networked Management Learning." Management Learning 35(2): 99-116.

Jones, K. (1989). A Sourcebook of Management Simulations. London, Kogan Page.

Marton, F. (1986). "Phenomenography - a Research Approach to Investigating Different Understandings of Reality." Journal of Thought 21(3): 28-49.

Marton, F. and S. Booth (1997). Learning and Awareness. New Jersey, Lawrence Erlbaum Associates.

Mintzberg, H. (2004). Managers not MBAs: a Hard Look at the Soft Practice of Managing and Management Development. London, Prentice Hall.

Pittaway, L. (2004). Simulating Entrepreneurial Learning: Assessing the Utility of Experiential Learning Designs. Lancaster, Lancaster University.

Prosser, M. and K. Trigwell (1999). Understanding Learning and Teaching: the Experience in Higher Education. Buckingham/Philadelphia, Society for Research into Higher Education \& Open University Press.

Revans, R. (1980). Action Learning: New Techniques for Management. London, Blond \& Briggs.

Roberts, G. (2004). Teaching Using the Web: Conceptions and Approaches from a Phenomenographic Perspective. Advances in Research on Networked Learning. P. Goodyear, S. Banks, V. Hodgson and D. McConnell. Boston, Kluwer Academic Publishers.

Robson, C. (2002). Real World Research: a Resource for Social Scientists and Practitioner-Researchers. Oxford, UK; Madden, Mass., Blackwell Publishers.

Spector, J. (2000). Building Theory into Practice in Learning and Instruction. Integrated and Holistic Perspectives on Learning, Instruction and Technology. J. Spector and T. Anderson. Dordrecht, Kluwer Academic Publishers.

Wankel, C. and R. DeFillippi, Eds. (2002). Rethinking Management Education for the 21st Century. Greenwich, Information Age Publishing. $\underline{\text { www.europen.de }}$

Endnotes:

${ }^{1}$ PUC and SEBRAE were mentioned to refer to other schools that run the PFN model.

${ }^{2}$ A role performed by the Central Office. Other services provided by the Central Office include insurance services (health, social, and possessions). The Central Office also functions as an accountancy counsellor, a supplier centre and a financial market. 